\title{
ANALISIS PELAKSANAAN DAN PENATAUSAHAAN DANA DESA PADA DESA-DESA DALAM WILAYAH KECAMATAN KOTAMOBAGU TIMUR, KOTA KOTAMOBAGU
}

\author{
Gresly Yunius Rainal Mamelo \\ Lintje Kalangi \\ Linda Lambey
}

(e-mail :gr35ly@gmail.com)

\begin{abstract}
Local autonomy authorizes local government to manage and operate their governance including villages as the smallest unit in supporting local development. UU number 16 year 2014 regulates villages and authorizes their local government to manage their own finance. Village fund management must be conducted in accordance with accountability, participatory and transparency as a responsibility fulfillment to public.

This study is an exploratory qualitative research. Content analysis was used to analyzed data which consists of data reduction, data display and conclusion. Respondent villages are Moyag Village and Kobo Kecil Village in District of East Kotamobagu, Kotamobagu City.

Results indicate that the implementation of village fund has been compiled in accordance to the regulation. However, there is a problem in the capability of human resources. Continuous trainings are needed to improve the capabilities of PTPKD and TPK Staff. On the other hand, computer application of SIMDA has been employed to administer the village fund, despite it has not been used optimally. Supervision for management staff is needed to improve the administration.
\end{abstract}

Keywords : Village Fund, Accountability, Participatory, Transparancy

\subsection{Latar Belakang Masalah}

\section{PENDAHULUAN}

Lahirnya UU (Undang-undang) No. 32 tahun 2004 sebagaimana telah diubah dengan UU No. 23 tahun 2014 tentang Pemerintah Daerah, menjelaskan adanya sistem desentralisasi, yaitu pelimpahan urusan pemerintahan oleh Pemerintah Pusat kepada Pemerintah Daerah. Adanya sistem desentralisasi membawa dampak perubahan besar bagi pertumbuhan nasional Indonesia. Hal ini ditunjukkan dengan adanya keberhasilan tiap daerah otonom dalam pertumbuhan ekonomi dan kemandirian membangun daerah masing-masing. Berbagai keberhasilan diraih baik di bidang Pendidikan, Pariwisata, Kesehatan, Infrastruktur dan berbagai apresiasi di berbagai bidang lainnya termasuk penghargaan Pemerintah Pusat terhadap kualitas pengelolaan keuangan daerah melalui Opini BPK (Badan Pemeriksa Keuangan) Republik Indonesia.

Keberhasilan yang ditunjukkan oleh tiap daerah Kabupaten/Kota dalam pengelolaan sumber daya yang ada, belum sepenuhnya berdampak pada kehidupan ekonomi masyarakat desa. Hal ini terlihat dengan masih tingginya angka kemiskinan di desa yang menimbulkan ketimpangan ekonomi antara desa dan kota. Desa seringkali tertinggal dalam berbagai aspek pembangunan jika dibandingkan dengan daerah kota.

Berbagai analisis dan gagasan kemudian mendorong Pemerintah untuk menetapkan UU No. 6 Tahun 2014 tentang Desa serta berbagai regulasi terkait pengelolaan dana desa. Ini membawa harapan baru masyarakat desa untuk membangun desanya masing-masing. Amanat undang-undang desa mensyaratkan agar desa mengelola keuangannya sendiri berdasarkan asas transparan, partisipatif dan akuntabel. 


\subsection{Rumusan Masalah}

Terkait dengan latar belakang yang diuraikan sebelumnya, maka penelitian ini membahas tentang pelaksanaan dan penatausahaan dana desa yang dilakukan oleh tiap desa di wilayah Kecamatan Kotamobagu Timur Kota Kotamobagu, dengan rumusan masalah sebagai berikut.

1. Apakah pelaksanaan dan penatausahaan dana desa oleh Pemerintah Desa di wilayah Kecamatan Kotamobagu Timur Kota Kotamobagu telah sesuai dengan yang ditetapkan oleh Pemerintah?

2. Apakah Pemerintah Daerah dan Pemerintah Desa telah mendorong pelaksanaan dan penatausahaan dana desa secara optimal?

\subsection{Tujuan Penelitian}

Penelitian ini bertujuan untuk menganalisis pelaksanaan dan penatausahaan dana desa di wilayah Pemerintah Daerah Kota Kotamobagu khususnya lagi di Kecamatan Kotamobagu Timur serta relevansinya dengan regulasi mengenai dana desa. Selain itu ingin melihat bagaimana upaya Pemerintah Daerah dan Pemerintah Desa dalam mengoptimalkan pemanfaatan dana desa guna peningkatan akuntabilitas, partisipatif dan transparansi. Bahkan ingin mengungkapkan apa saja permasalahan yang ditemui oleh Pemerintah Desa dalam pengelolaan dana desa ini.

\subsection{Manfaat Penelitian}

Hasil penelitian ini diharapkan dapat memberikan manfaat yang berarti bagi Pemerintah Daerah dan Akademisi.

1. Bagi Pemerintah Daerah Kota Kotamobagu, diharapkan menjadi masukan dalam mendukung pelaksanaan otonomi daerah khususnya sebagai sumbang saran kepada Pemerintah Kota Kotamobagu lebih khusus lagi Pemerintah Desa dalam pengelolaan program dana desa yang akuntabel, transparan dan partisipatif.

2. Bagi para akademisi hasil penelitian ini diharapkan dapat memberikan kontribusi terhadap pengembangan literatur Akuntansi Sektor Publik (ASP), selanjutnya dapat dijadikan sebagai acuan guna penelitian lanjutan.

\subsection{Landasan Teoritis}

\section{TINJAUAN PUSTAKA}

\section{Teori Keadilan}

Teori keadilan yang diangkat adalah Teori Keadilan menurut John Stuart Mill dan John Rawls, sebagai berikut.

1. Teori Keadilan menurut John Stuart Mill (1806 - 1873)

Ide dasar utilitarianisme sangat sederhana : yang benar untuk dilakukan adalah yang menghasilkan kebaikan terbesar. Karena fakta menunjukkan bahwa ide seperti ini merupakan cara banyak orang mendekati putusan-putusan etis, sangat mudah untuk melihat kenapa teori ini memiliki daya tarik yang sangat besar. Definisi singkat prinsip keadilan utilitarian dikemukakan Mill, yaitu 'Kemanfaatan' atau 'prinsip kebahagiaan terbesar' menyatakan bahwa tindakan tertentu benar jika cenderung memperbesar kebahagiaan; keliru jika cenderung menghasilkan berkurangnya kebahagiaan.

Mill dikutip oleh Lebacqz (1986) menyimpulkan bahwa tidak ada teori keadilan yang bisa dipisahkan dari tuntutan kemanfaatan. Keadilan adalah istilah yang diberikan kepada aturan-aturan yang melindungi klaim-klaim yang dianggap esensial bagi kesejahteraan masyarakat.

Klaim-klaim untuk memegang janji, diperlakukan dengan setara dan sebagainya. Sifat-sifat esensial keadilan didalam skema utilitarian yaitu, Keadilan mengakui eksistensi hak-hak individu yang didukung masyarakat. Keadilan bagi Mill mensyaratkan aturan-aturan yang ditetapkan menjadi kebaikan masyarakat demi menjamin pemenuhan kewajiban-kewajiban tertentu yang keras dan demi melindungi hak-hak individu. 
Keadilan bisa memadukan konsep mengenai perlakuan setara dan konsep pengabaian. Namun yang terpenting adalah keadilan bergantung sepenuhnya pada kemanfaatan sosial sebagai fondasinya. Karena itulah, semua aturan keadilan, termasuk kesetaraan bisa tunduk kepada tuntutan kemanfaatan. Apapun yang membawa kebaikan terbesar bagi semuanya dapat disebut adil.

Teori ini sejalan dengan Program Pemerintah melalui Dana Desa. Pemerintah berpandangan bahwa dengan menyalurkan belanja pemerintah langsung ke desa, ini dapat meningkatkan perekonomian masyarakat desa, dengan demikian desa akan semakin maju serta semakin mandiri dalam pembangunannya. Negara menunjukkan rasa adilnya kepada masyarakat desa yang butuh diperhatikan.

2. Teori Keadilan menurut John Rawls (1921 - 2002)

John Rawls mengajukan sebuah teori alternatif mengenai keadilan dengan menghindari kelemahan utilitarianisme sambil mempertahankan kekuatan yang sama. Berharap dapat merumuskan sebuah teori yang dapat mengakomodasikan pribadi individu secara serius tanpa mempertaruhkan kesejahteraan atau hak-haknya demi kebaikan orang lain, sekaligus menawarkan sebuah metode yang konkret untuk membuat suatu keputusan yang fundamental mengenai keadilan distributif. Hasilnya adalah keadilan sebagai kesetaraan (justice as fairness).

Prinsip-prinsip keadilan menurut Rawls diperoleh bukan dengan mengevaluasi kemanfaatan dari tindakan-tindakan melainkan dari pilihan rasional didalam kondisi yang adil. Prinsip-prinsip tersebut dilekatkan pada struktur dasar masyarakat, bukannya setiap tindakan atau setiap tingkatan dimana keadilan dipersoalkan. Rawls lebih menyoroti masalah tataran makro ketimbang mikro.

A Theory of Justice menawarkan sebuah teori yang kompleks sekaligus ketat, berbasis pemahaman cemerlang mengenai potensi penggunaan kontrak sosial sebagai basis teori keadilan. Lebih penting lagi, jika pendekatan utilitarianisme Mill menjadikan individu rapuh terhadap tuntutan kebaikan terbesar orang lain, maka prinsip Rawls jelas melindungi pihak-pihak yang paling kurang beruntung di masyarakat. Tidak ada pertukaran kebebasan atau kesejahteraan mereka dengan kesejahteraan orang lain yang diperbolehkan.

Kebebasan-kebebasan dasar harus didistribusikan setara dan tidak boleh dikorbankan demi pencapaian ekonomi. Intinya adalah untuk menjadikan pihak yang kurang beruntung menjadi lebih baik dari kondisi sebelumnya. Teori ini juga mendukung program dana desa, dimana masyarakat desa sebagai komunitas yang kurang mendapat perhatian haruslah menjadi fokus pembangunan, sehingga pembangunan tidak hanya dalam kota saja tetapi pedesaanpun boleh berkembang sebagaimana perkembangan kota.

\section{Teori Keagenan}

Teori keagenan menjelaskan hubungan antara prinsipal dan agen yang berakar pada teori ekonomi, teori keputusan, sosiologi dan teori organisasi (DeGeorge, 1992 dikutip oleh Smith \& Bertozzi, 1998). Teori keagenan menganalisis susunan kontraktual di antara dua atau lebih individu, kelompok atau organisasi. Salah satu pihak (principal) membuat suatu kontrak, baik secara implisit maupun eksplisit dengan pihak lain (agent) dengan harapan agen akan bertindak atau melakukan pekerjaan seperti yang diinginkan oleh prinsipal.

Kesepakatan atau kontrak yang dimaksud disini adalah pendelegasian wewenang kepada agen untuk melakukan semua pekerjaan secara bertanggungjawab. Dalam hal ini dengan pengelolaan Dana Desa oleh Pemerintah Desa (agent), mereka bertanggungjawab kepada masyarakat desa (principal) sebagai pemberi amanah dalam pelaksanaan tugas pembangunan dan pemerintahan di desa.

\section{Implementasi Kebijakan}

Istilah Kebijakan (policy) seringkali disamaartikan dengan penggunaan istilah-istilah lain seperti tujuan (goals), program, keputusan, undang-undang, ketentuan-ketentuan ataupun 
usulan-usulan. Namun hal ini bukan masalah bagi pembuat kebijakan (policy makers), tetapi menjadi masalah bagi mereka yang berada di luar struktur pengambilan kebijakan. Anderson (1984) dikutip oleh Tahir (2014) mendefinisikan kebijakan sebagai suatu tindakan dengan tujuan untuk memecahkan masalah. Anderson membagi kebijakan menjadi dua yaitu kebijakan prosedural dan kebijakan substantif. Kebijakan substantif mengenai apa yang harus dikerjakan oleh Pemerintah, sedangkan kebijakan prosedural adalah siapa dan bagaimana kebijakan tersebut diselenggarakan. Ini berarti kebijakan publik adalah kebijakan-kebijakan yang dibuat/dikembangkan oleh badan-badan dan pejabat-pejabat Pemerintah.

Apapun produk kebijakan itu dari Pemerintah, pada akhirnya bermuara pada tataran bagaimana mengimplementasikan kebijakan tersebut teraktualisasi. Keberhasilan suatu implementasi kebijakan ditentukan oleh banyak faktor, dan masing-masing faktor tersebut saling berhubungan satu sama lain. Edward III (1980:9) dikutip oleh Tahir (2014), mengemukakan bahwa di dalam pendekatan studi implementasi kebijakan, pertanyaan abstraknya dimulai dari bagaimana pra kondisi untuk suksesnya kebijakan publik dan kedua adalah apa hambatan utama dari kesuksesan kebijakan publik.

Untuk menjawab pertanyaan penting tersebut, maka Edward III menawarkan dan mempertimbangkan empat faktor dalam mengimplementasikan kebijakan publik, yakni: Communication, Resources, Disposition or Attitudes and Bureaucratic Structure, menjelaskan empat faktor dimaksud yakni komunikasi, sumber daya, sikap pelaksana dan struktur birokrasi.

\section{Pengelolaan Dana Desa}

Dalam Permendagri No. 113 tahun 2014, Pengelolaan Keuangan Desa adalah keseluruhan kegiatan yang meliputi perencanaan, pelaksanaan, penatausahaan dan pertanggungjawaban keuangan desa. Namun dalam penelitian ini yang lebih difokuskan adalah pada proses pelaksanaan dan penatausahaan dana desa.

1. Pelaksanaan

Dalam pelaksanaan anggaran desa yang sudah ditetapkan sebelumnya timbul transaksi penerimaan dan pengeluaran desa. Semua penerimaan dan pengeluaran desa dalam rangka pelaksanaan kewenangan desa dilaksanakan melalui rekening kas desa. Jika desa yang belum memiliki pelayanan perbankan di wilayahnya maka pengaturannya ditetapkan oleh Pemerintah Kabupaten/Kota. Semua penerimaan dan pengeluaran desa harus didukung oleh bukti yang lengkap dan sah.

Beberapa aturan dalam pelaksanaan pengelolaan keuangan desa sebagai berikut.

a. Pemerintah desa dilarang melakukan pungutan sebagai penerimaan desa selain yang ditetapkan dalam peraturan desa;

b. Bendahara dapat menyimpan uang Kas Desa pada jumlah tertentu dalam rangka memenuhi kebutuhan operasional pemerintah desa;

c. Pengaturan jumlah uang dalam kas desa ditetapkan dalam Peraturan Bupati/Walikota;

d. Pengeluaran desa yang mengakibatkan beban pada APBDesa tidak dapat dilakukan sebelum Rancangan Peraturan Desa tentang APBDesa ditetapkan menjadi Peraturan Desa;

e. Pengeluaran desa tidak termasuk untuk belanja pegawai yang bersifat mengikat dan operasional perkantoran yang ditetapkan dalam peraturan kepala desa;

f. Penggunaan biaya tak terduga terlebih dulu harus dibuat Rincian Anggaran Biaya yang telah disahkan oleh Kepala Desa;

g. Pelaksana kegiatan yang mengajukan pendanaan untuk melaksanakan kegiatan harus disertai dengan dokumen antara lain Rencana Anggaran Biaya;

h. Rencana Anggaran Biaya diverifikasi oleh Sekretaris Desa dan disahkan oleh Kepala Desa;

i. Pelaksana kegiatan bertanggungjawab terhadap tindakan pengeluaran yang menyebabkan atas beban anggaran belanja kegiatan dengan mempergunakan buku pembantu kas kegiatan sebagai pertanggungjawaban.

2. Penatausahaan 
Kepala desa dalam melaksanakan penatausahaan keuangan desa harus menetapkan bendahara desa. Penetapan bendahara desa harus dilakukan sebelum dimulainya tahun anggaran bersangkutan dan berdasarkan keputusan kepala desa. Menurut Ardi Hamzah (2015) dikutip oleh Sujarweni (2015), Bendahara adalah perangkat desa yang ditunjuk oleh kepala desa dalam rangka pelaksanaan APBDesa. Bendahara desa wajib mempertanggungjawabkan uang melalui laporan pertanggungjawaban. Laporan pertanggungjawaban disampaikan setiap bulan kepada Kepala Desa dan paling lambat tanggal 10 bulan berikutnya. Dalam Permendagri No. 113 tahun 2014 laporan pertanggungjawaban yang wajib dibuat oleh bendahara desa adalah sebagai berikut.

a. Buku Kas Umum

Buku kas umum digunakan untuk mencatat berbagai aktivitas yang menyangkut penerimaan dan pengeluaran kas, baik secara tunai maupun kredit, digunakan juga untuk mencatat mutasi perbankan atau kesalahan dalam pembukuan. Buku kas umum dapat dikatakan sebagai sumber dokumen transaksi.

b. Buku Pembantu Pajak

Buku pajak digunakan untuk membantu buku kas umum, dalam rangka penerimaan dan pengeluaran yang berhubungan dengan pajak.

c. Buku Bank

Buku bank digunakan untuk membantu buku kas umum, dalam rangka penerimaan dan pengeluaran yang berhubungan dengan uang bank.

\section{SIMDA Desa}

SIMDA Desa merupakan aplikasi yang dikembangkan oleh Badan Pengawasan Keuangan dan Pembangunan (BPKP) dalam rangka meningkatkan kualitas tata kelola keuangan desa. Sebelumnya Aplikasi ini dikembangkan oleh Perwakilan BPKP Provinsi Sulawesi Barat sebagai proyek percontohan di Lingkungan BPKP pada bulan Mei 2015. Namun terhitung mulai tanggal 13 Juli 2015 pengembangan aplikasi keuangan desa ini telah diambil alih penanganan sepenuhnya oleh Deputi Bidang Pengawasan Penyelenggaraan Keuangan Daerah BPKP Pusat di Jakarta setelah melewati tahapan Quality Assurance (QA) oleh Tim yang telah ditunjuk.

Fitur-fitur yang ada dalam aplikasi SIMDA Desa dibuat sederhana dan user friendly sehingga memudahkan pengguna dalam mengoperasikan aplikasi SIMDA Desa. Dengan proses penginputan sekali sesuai dengan transaksi yang ada dapat menghasilkan output berupa dokumen penatausahaan dan laporan-laporan yang sesuai dengan ketentuan perundangundangan, antara lain sebagai berikut.

1. Dokumen penatausahaan,

2. Bukti penerimaan,

3. Surat Permintaan Pembayaran (SPP),

4. Surat Setoran Pajak (SSP),

5. Dan dokumen-dokumen lainnya,

6. Laporan-laporan,

7. Laporan Penganggaran (Perdes APBDesa, RAB, APB Desa per sumber dana),

8. Laporan Penatausahaan (Buku Kas Umum, Buku Bank, Buku Pajak, Buku Pembantu dan Register.

\subsection{Penelitian Terdahulu}

Penelitian Sumiati (2015) dengan judul "Pengelolaan Alokasi Dana Desa (ADD) pada Desa Ngatabaru Kecamatan Sigi Biromaru Kabupaten Sigi." Metode penelitian yang digunakan merupakan penelitian kualitatif di Desa Ngatabaru yang dilaksanakan kurang lebih 3 (tiga) bulan dengan menggunakan data utama melalui wawancara serta data sekunder melalui data yang diperoleh dari studi referensi maupun dokumen-dokumen yang terkait. hasil penelitian yang dilakukan menyimpulkan bahwa penerapan fungsi-fungsi manajemen terhadap pengelolaan alokasi dana desa pada Desa Ngatabaru Kecamatan Sigi Biromaru Kabupaten Sigi tidak optimal. Hal ini 
terlihat dalam administrasi perencanaan yang dilakukan atas Alokasi Dana Desa oleh aparat Pemerintah Desa Ngatabaru tidak berjalan dengan baik karena tidak mempertimbangkan masalah yang akan terjadi pada saat pelaksanaan program-program kegiatan.

Penelitian Suparman et al (2014) yang berjudul "Implementasi Program Alokasi Dana Desa (ADD) di Kecamatan Sukadana Kabupaten Kayong Utara." Metode Penelitian yang digunakan adalah jenis penelitian deskriptif dalam pendekatan kualitatif. Teknik pengumpulan data yang digunakan adalah teknik observasi, wawancara dan studi dokumentasi. Penelitian ini mendeskripsikan tentang proses implementasi program Alokasi Dana Desa (ADD) yang dilihat dari indikator pengorganisasian, interpretasi dan aplikasi serta faktor-faktor yang mempengaruhi proses implementasi program ADD di Kecamatan Sukadana Kabupaten Kayong Utara, dilihat dari faktor sumber daya manusia dan sumber daya dana, faktor sosialisasi penyaluran dana dan faktor koordinasi. Hasil penelitian menunjukkan bahwa proses implementasi program ADD di Kecamatan Sukadana belum sepenuhnya mengarah pada pengembangan sosial ekonomi masyarakat desa.

Penelitian Sukanto (2014) dengan judul "Efektifitas Alokasi Dana Desa (ADD) dan Kemiskinan di Provinsi Sumatera Selatan" menggunakan metode penelitian deskriptif kualitatif dan analisis inferensial berupa regresi sederhana. Hasil kajian menemukan beberapa hal yang berkaitan dengan permasalahan dalam penelitian ini, yaitu: penyaluran ADD belum sesuai dengan ketentuan yang berlaku. Hasil regresi sederhana menunjukkan adanya pengaruh yang negatif antara ADD terhadap tingkat kemiskinan, demikian juga hasil simulasi ADD minimal $10 \%$ terhadap kemiskinan-pun menunjukkan hubungan yang negatif.

Penelitian Hargono (2010) dengan judul Tesis "Efektifitas Penyaluran Alokasi Dana Desa pada Empat Desa di Kabupaten Karangasem Propinsi Bali." Penelitian ini bertujuan untuk mengetahui efektifitas penyaluran alokasi dana desa pada empat desa sampel di empat kecamatan yang berbeda di Kabupaten Karangasem, Propinsi Bali dan disparitas (kesenjangan) pembangunan antar kecamatan. Hasil yang diperoleh bahwa besarnya Alokasi Dana Desa yang diberikan ke setiap desa tidak menggunakan formula yang ditentukan dengan pembobotan tujuh variabel penting desa, tetapi menggunakan pembagian total jumlah desa di Kabupaten untuk penentuan ADDM (ADD Merata) dan pembagian total jumlah banjar dinas untuk penentuan ADDP (ADD Proporsional).

Penelitian Wisakti (2008) dengan judul Tesis "Implementasi Kebijakan Alokasi Dana Desa di Wilayah Kecamatan Geyer Kabupaten Grobogan." Tujuan Penelitian ini adalah untuk memberikan gambaran pelaksanaan alokasi dana desa di Kecamatan Geyer Kabupaten Grobogan serta faktorfaktor penunjang dan penghambat yang mempengaruhi implementasi dan strategi yang harus dilakukan dalam rangka keberhasilan implementasi kebijakan selain itu juga akan memberikan rekomendasi bagi Pemerintah Daerah dalam pengelolaan alokasi dana desa. Hasil penelitian menunjukkan bahwa implementasi kebijakan Alokasi Dana Desa (ADD) di Kecamatan Geyer Kabupaten Grobogan berjalan cukup lancar. Namun demikian apabila dikaitkan dengan pencapaian tujuan, pelaksanaan Alokasi Dana Desa belum optimal.

\subsection{Pertanyaan Riset}

\section{KERANGKA KONSEPTUAL}

Pertanyaan riset dirumuskan sebagai berikut.

1. Apakah pelaksanaan dan penatausahaan dana desa pada desa-desa di Kecamatan Kotamobagu Timur sudah sesuai dengan regulasi yang dibuat oleh Pemerintah?

2. Apakah Pemerintah Daerah dan Pemerintah Desa sudah mendorong pemanfaatan dana desa secara optimal?

\subsection{Proposisi}

Berdasarkan pertanyaan riset yang diuraikan di atas, maka proposisi yang dibangun adalah sebagai berikut.

1. Pelaksanaan dan penatausahaan dana desa pada desa-desa di Kecamatan Kotamobagu Timur sudah sesuai dengan Permendagri No. 113 tahun 2014. 
2. Pemerintah Daerah dan Pemerintah Desa sudah mendorong pemanfaatan dana desa secara optimal.

\subsection{Jenis Penelitian}

\section{METODE PENELITIAN}

Untuk melihat sejauh mana implementasi program dana desa khususnya dalam pelaksanaan dan penatausahaanya oleh Pemerintah Desa, juga melihat bagaimana upaya Pemerintah Desa dalam mengoptimalkan pemanfaatan dana desa, maka digunakan metode penelitian kualitatif deskriptif dengan pendekatan eksploratif yakni penelitian yang bertujuan untuk mengembangkan pengetahuan atau dugaan yang sifatnya masih baru dan untuk memberikan arahan bagi penelitian selanjutnya.

\subsection{Sumber Data}

Sumber data yang digunakan pada penelitian ini adalah sebagai berikut, yaitu data primer, yaitu data yang diperoleh dengan melakukan wawancara mendalam kepada informan kunci yaitu perangkat desa dan data sekunder, yaitu data yang diperoleh dari dokumen-dokumen yang berkaitan dengan pembahasan, literatur, serta sumber lainnya yang berkaitan dengan objek penelitian.

\subsection{Teknik Pengumpulan Data}

Menurut Satori dan Komariah (2014:103), dalam penelitian kualitatif teknik pengumpulan data dapat dilakukan melalui setting dari berbagai sumber, dan berbagai cara. Adapun teknik pengumpulan data yang digunakan dalam penelitian ini adalah sebagai berikut wawancara, observasi dan dokumentasi.

\subsection{Instrumen Penelitian}

Instrumen kunci dari penelitian ini adalah peneliti sendiri dan untuk menggali informasi dari informan dalam metode wawancara, Peneliti menggunakan interview questions.

\subsection{Lokasi dan Waktu Penelitian}

Penelitian ini difokuskan di 2 desa yang ada di Kecamatan Kotamobagu Timur yaitu Desa Moyag dan Desa Kobo Kecil. Sebelumnya Peneliti hendak melakukan penelitian terhadap 4 desa di Kecamatan Kotamobagu Timur, yakni Desa Kobo Kecil, Desa Moyag, Desa Moyag Tampoan dan Desa Moyag Todulan, namun karena Desa Moyag Todulan dan Desa Moyag Tampoan belum mengelola dana desa tahun 2016 oleh karena permasalahan administrasi pada Pemerintah Pusat, maka Peneliti hanya memfokuskan pada desa yang telah mengelola dana desa tahun 2016 di Kecamatan Kotamobagu Timur, yakni Desa Moyag dan Kobo Kecil. Penelitian ini akan diintensifkan pelaksanaannya selama \pm 2 bulan. Dan dengan waktu yang terbatas ini, sangat berharap dapat mendeskripsikan pelaksanaan dan penatausahaan dana desa di wilayah Pemerintah Daerah Kota Kotamobagu, khususnya pada desa-desa yang menjadi fokus penelitian.

\subsection{Teknik Analisis Data}

Teknik analisis data yang digunakan dalam penelitian ini adalah Teknik Analisis Model Milles dan Huberman. Aktivitas analisis data Miles dan Huberman dikutip oleh Satori et al (2014) terdiri atas: data reduction, data display dan drawing conclusion/verification yang dilakukan secara interaktif dan berlangsung secara terus menerus sampai tuntas, sehingga datanya mencapai jenuh.

\subsection{Gambaran Umum Objek Penelitian}

\section{HASIL ANALISIS DAN PEMBAHASAN}

Luas wilayah Kecamatan Kotamobagu Timur $\pm 30.1 \mathrm{~km} 2$ yang terbagi dalam 6 Kelurahan yakni Kelurahan Kotobangon, Kelurahan Sinindian, Kelurahan Matali, Kelurahan Motoboi Besar, Kelurahan Kobo Besar, Kelurahan Tumobui dan 4 desa yakni, Desa Moyag, Desa Moyag Tampoan, Desa Moyag Todulan dan Desa Kobo Kecil. 
Tabel 5.1 : Data Jumlah Penduduk, Jumlah Penduduk Miskin, Luas Wilayah dan IKG Di Desa Moyag dan Kobo Kecil Tahun 2015

\begin{tabular}{|c|l|c|c|c|c|}
\hline No & Nama Desa & $\begin{array}{c}\text { Jumlah } \\
\text { Penduduk }\end{array}$ & $\begin{array}{c}\text { Jumlah } \\
\text { Penduduk } \\
\text { Miskin }\end{array}$ & $\begin{array}{c}\text { Luas } \\
\text { Wilayah }\end{array}$ & IKG \\
\hline 1 & Desa Moyag & 2349 & 35 & $5,74 \mathrm{~km} 2$ & 38,65 \\
\hline 2 & Kobo Kecil & 2888 & 329 & $2,58 \mathrm{~km} 2$ & 37,97 \\
\hline
\end{tabular}

Sumber : Badan Pusat Statistik Kota Kotamobagu, 2015

\subsection{Pelaksanaan dan Penatausahaan Dana Desa di Kecamatan Kotamobagu Timur}

Tahun 2016 merupakan tahun kedua bagi Pemerintah Kota Kotamobagu mendapatkan transfer dana desa dari Pemerintah Pusat. Adapun Kecamatan Kotamobagu Timur mendapatkan anggaran dana desa sebesar Rp. 1.725.332.870,- yang dibagi kepada 2 (dua) desa, yakni Desa Moyag dan Desa Kobo Kecil seperti dalam Tabel 5.10 berikut.

Tabel 5.10 : Rincian Dana Desa di Kecamatan Kotamobagu Timur Kota Kotamobagu Tahun 2016

\begin{tabular}{|c|l|c|c|r|}
\hline No. & \multicolumn{1}{|c|}{ Nama Desa } & $\begin{array}{c}\text { Alokasi Dasar } \\
(\mathrm{Rp})\end{array}$ & $\begin{array}{c}\text { Alokasi } \\
\text { Formula (Rp) }\end{array}$ & $\begin{array}{c}\text { Total Pagu Dana } \\
\text { Desa (Rp) }\end{array}$ \\
\hline 1 & Desa Moyag & 565.640 .000 & 235.736 .561 & 801.377 .000 \\
\hline 2 & Desa Kobo Kecil & 565.640 .000 & 358.316 .309 & 923.956 .000 \\
\hline \multicolumn{4}{|c|}{ To t a l } & 1.725 .333 .000 \\
\hline
\end{tabular}

Sumber : Lampiran Peraturan Walikota Kotamobagu No. 4, 2016

Pelaksanaan dan penatausahaan dana desa di Kota Kotamobagu didasarkan pada Peraturan Walikota Kotamobagu No. 15 tahun 2015 tentang Tata Cara Penatausahaan dan Penyusunan Laporan Pertanggungjawaban Dana Desa yang merupakan peraturan yang disadur dari Permendagri No. 113 tahun 2014. Bahkan untuk memfasilitasi pengelolaan dana desa itu sendiri, Pemerintah Daerah telah membentuk Tim Fasilitasi Dana Desa melalui Keputusan Walikota No. 37 tahun 2016. Tim Fasilitasi ini terdiri dari unsur SKPD (Satuan Kerja Perangkat Daerah) teknis seperti Dinas Pendapatan, Pengelolaan Keuangan dan Aset Daerah, Dinas Pekerjaan Umum, Badan Pemberdayaan Masyarakat Desa, Dinas Kesehatan, Bagian Pembangunan, Bagian Hukum, Inspektorat Daerah dan beberapa SKPD lainnya.

\subsection{Analisis dan Pembahasan}

Berdasarkan latar belakang masalah, landasan teori dan metode penelitian yang diuraikan sebelumnya, maka pada sub bab ini akan disajikan hasil analisis dan pembahasan melalui wawancara langsung dengan informan terpilih, yaitu pelaksana dan pengelola kegiatan dana desa di Desa Kobo Kecil dan Desa Moyag. Data wawancara, data observasi dan data dokumentasi yang diperoleh kemudian dilakukan pengorganisasian data dan dilakukan pemahaman untuk menentukan tema.

\section{Komitmen}

Pemerintah Kota Kotamobagu telah menerbitkan peraturan tentang Tata Cara Penatausahaan dan Penyusunan Laporan Pertanggungjawaban Dana Desa, yaitu Peraturan Walikota nomor 15 tahun 2015 serta beberapa regulasi terkait lainnya. Disamping itu Pemerintah Kota Kotamobagu telah melaksanakan Bimbingan Teknis bagi Pengelola Keuangan Desa pada tahun 2015.

Dengan menerbitkan regulasi terkait pengelolaan dana desa serta melaksanakan Bimbingan Teknis bagi pengelola keuangan desa, menunjukkan bahwa Pemerintah Kota Kotamobagu memiliki komitmen yang kuat guna mendukung akuntabilitas pengelolaan dana desa. Komitmen pimpinan sebagai bentuk dukungan sangatlah dibutuhkan dalam mendukung pengelolaan dana desa. Hal-hal tersebutlah yang menjadi nilai tambah yang dimiliki oleh Pemerintah Kota Kotamobagu sehingga mampu menerapkan kebijakan tersebut dengan baik. 


\section{Transparan dan Partisipatif}

Partisipatif dengan melibatkan masyarakat dalam perencanaan dana desa serta berupaya transparan dengan memberikan keterbukaan informasi akan apa saja kegiatan yang dilaksanakan, anggaran yang digunakan serta waktu pengerjaannya.

\section{Akuntabel}

Dengan memperkuat struktur pengelolaan dana desa melalui fungsi TPK dan Pelaksana Kegiatan, maka Pemerintah Desa telah menunjukkan tanggungjawab besarnya kepada masyarakat selaku pemberi amanah untuk melakukan pengelolaan dana desa berdasarkan prinsip akuntabel. Seperti yang dijelaskan oleh DeGeorge (1992) dikutip oleh Smith \& Bertozzi (1998) bahwa agent (Pemerintah) terikat kontrak dengan principal (masyarakat) untuk bertindak atau melakukan pekerjaan seperti yang diinginkan oleh principal.

Hubungan antara agent dan principal membawa kepada ketidakseimbangan informasi (asymetrical information), dimana apa yang diusulkan masyarakat untuk dianggarkan dalam dana desa belum tentu dapat diakomodir seluruhnya oleh Pemerintah Desa, karena atas dasar Program Prioritas Pemerintah Pusat dan Daerah sehingga Pemerintah Desa hanya dapat menganggarkan bidang kegiatan yang hanya sesuai dengan Program Prioritas dari Pemerintah Pusat dan Daerah.

\section{Faktor Struktur Birokrasi}

Dalam prakteknya Pemerintah Desa belum memiliki SOP terkait pelaksanaan dan penatausahaan dana desa. Edward III dikutip oleh Tahir (2014) menjelaskan bahwa keberhasilan implementasi kebijakan juga dipengaruhi oleh faktor struktur birokrasi. Salah satu aspek struktur birokrasi yang penting dari setiap organisasi adalah adanya prosedur operasi yang standar. Standar inilah yang menjadi pedoman bagi setiap implementor dalam bertindak.

Standar prosedur pengoperasian (Standard Operating Procedure/SOP) menurut Macintosh dan Dalf (1987) dikutip oleh Wiyantoro dan Sabeni (2007) adalah sejumlah aturan yang tertulis, prosedur, kebijakan dan operasi manual yang digunakan untuk menuntun manajer mengatur departemen mereka. Termasuk juga didalamnya petunjuk kebijakan umum, pembagian tugas dan petunjuk bagaimana seharusnya menangani situasi operasional yang timbul.

\subsection{Kesimpulan}

\section{KESIMPULAN DAN SARAN}

Dari hasil Analisis Pelaksanaan dan Penatausahaan Dana Desa di Desa-desa dalam Wilayah Kecamatan Kotamobagu Timur yang uraikan di atas, maka dapat ditarik kesimpulan sebagai berikut.

1. Pelaksanaan Dana Desa di Desa Moyag dan Desa Kobo Kecil pada prinsipnya telah dilakukan berdasarkan regulasi. Namun belum semua pekerjaan dilakukan dengan tertib administrasi. Pelaksanaannya belum sepenuhnya mendukung asas-asas pengelolaan keuangan desa. Selain itu Pemerintah Desa belum memiliki SOP (standard operating procedure) terkait pelaksanaan dana desa. Ini dibutuhkan guna mendukung implementasi program dana desa.

2. Penatausahaan Dana Desa di Desa Moyag dan Desa Kobo Kecil pada dasarnya memiliki kemudahan, yakni dengan adanya Aplikasi Sistem Keuangan Desa. Namun Aplikasi ini belum dimanfaatkan secara maksimal oleh Pemerintah Desa.

\subsection{Saran}

Dari analisis yang dilakukan terhadap pelaksanaan dan penatausahaan dana desa, saran yang diharapkan dapat mendorong Akuntabilitas pelaksanaan dan penatausahaan dana desa adalah sebagai berikut.

1. Guna mendorong tujuan dari pengelolaan dana desa yaitu tertib dan disiplin anggaran, maka diharapkan Kepala Desa dapat meningkatkan pengawasan (supervision) terhadap PTPKD dan TPK dalam hal tertib pelaksanaan dan penatausahaan. Aris (2001) dikutip oleh Silalahi 
(2014) menjelaskan bahwa pengawasan/supervisi merupakan tindakan mengawasi atau mengarahkan penyelesaian pekerjaan. Dengan pengawasan yang efektif tentunya akan memberikan jaminan kepada Kepala Desa bahwa Perangkat Desa bekerja dengan sebaikbaiknya.

2. Pembinaan dan pelatihan PTPKD dan TPK merupakah sarana efektif untuk mendorong pengelolaan keuangan desa yang baik. Pengelola Keuangan maupun Pengelola Kegiatan harus terus belajar bahkan dilatih untuk semakin terampil melaksanakan tugas-tugas dan tanggungjawab mereka. Pemerintah Daerah harus melaksanakan pelatihan secara continue kepada PTPKD dan TPK. Ruky (2001:163) mendefinisikan Pelatihan sebagai usaha untuk meningkatkan atau memperbaiki kinerja karyawan dalam pekerjaannya sekarang dan dalam pekerjaan lain yang terkait dengan yang sekarang dijabatnya, baik secara individu maupun sebagai bagian dari sebuah tim kerja. Melalui pelatihan ini, Perangkat Desa dapat secara bersama-sama membahas persoalan yang ditemui saat pelaksanaan kegiatan serta menyamakan persepsi bila terdapat beda pemahaman terkait pengelolaan dan pelaksanaan anggaran dana desa.

\section{DAFTAR PUSTAKA}

Alvin, Silvanus. 2015. Kenaikan Alokasi Dana Desa Rawan Diselewengkan. Halaman : http://news.liputan6.com/read/2328919/icw-kenaikan-alokasi-dana-desa-rawandiselewengkan diakses tanggal 30 Januari 2016

Ari. 2011. Perangkat Desa datangi Istana Negara. Halaman : http://news.liputan6.com/read/366506/perangkat-desa-datangi-istana-negara diakses tanggal 16 Maret 2016

Badan Pengawasan Keuangan dan Pembangunan. Halaman : http://www.bpkp.go.id/sakd/konten/2448/Leaflet-Simda-Desa.bpkp diakses pada tanggal 2 September 2016.

Badan Pusat Statistik. 2014. Jumlah Penduduk Miskin, Persentase Penduduk Miskin dan Garis Kemiskinan, Tahun 1970 - 2013. Halaman : http://bps.go.id/linkTabelStatis/view/id/1494 diakses pada tanggal 25 Februari 2016

Bungin, Burhan. 2015. Penelitian Kualitatif. Jakarta : Prenada Media Group

Chandoevwit, Worawan and Bawornpan Ashakul. 2008. The Impact of the Village Fund on Rural Households. Thailand Development Research Institute Quarterly Review Vol. 23 No. 2

Direktorat Jenderal Perimbanan Keuangan Kementerian Keuangan. 2015. Rincian Dana Transfer ke Daerah dan Dana Desa pada APBN-P 2015. Halaman: http://www.djpk.kemenkeu.go.id/web/attachments/article/608/DANADESA2016.pdf diakses pada 25 Februari 2016

Direktorat Jenderal Perimbanan Keuangan Kementerian Keuangan. 2015. Rincian Dana Desa Tahun Anggaran 2016. Halaman

http://www.djpk.kemenkeu.go.id/web/attachments/article/608/DANADESA2016.pdf diakses pada 25 Februari 2016

Duadji, Noverman. 2012. Good Governance dalam Pemerintah Daerah. Mimbar (Vol. 28). No. 2: 201-209

Halim, Abdul dan Muhammad Iqbal. 2012. Pengelolaan Keuangan Daerah. Edisi Ketiga, Cetakan Pertama. Yogyakarta : Sekolah Tinggi Ilmu Manajemen YKPN.

Hargono, S. Didiek. 2010. Efektifitas Penyaluran Alokasi Dana Desa Pada Empat Desa di Kabupaten Karangasem Propinsi Bali. Tesis : Fakultas Ekonomi Program Studi Magister Perencanaan dan Kebijakan Publik Universitas Indonesia

Henry, Lopulalan. 2014. Nawa Cita, 9 Agenda Prioritas Jokowi-JK. Halaman : http://nasional.kompas.com/read/2014/05/21/0754454/.nawa.cita.9.agenda.prioritas.jokowi -jk diakses tanggal 30 Januari 2016

Hutapea, P dan Nurianna Thoha. 2008. Kompetensi Plus (Teori, Desain, Kasus dan Penerapan untuk HR serta Organisasi yang dinamis). Jakarta : PT. Gramedia Pustaka Utama 
Kota Kotamobagu. 2016. Tata Cara Pembagian dan Penetapan Rincian Dana Desa setiap Desa Tahun Anggaran 2016. Peraturan Walikota No. 4

Kuncoro, Mudrajad. 2009. Metode Riset untuk Bisnis \& Ekonomi. Jakarta : Erlangga

Lambey, Linda. 2008. Lessons From Sub-National Local Government Fiscal Structure : State of Georgia, USA. Jurnal Pembangunan Ekonomi dan Pembangunan Daerah. (Vol. 1. No. 1)

Lambey, Linda. 2015. Mental Models of employment and the psychological contracts of Indonesian academics: an exploratory study. Thesis Doctor of Philosophy, Newcastle Business School, University of Newcastle, Australia

Lebacqz, Karen. 1986. Teori-teori Keadilan. Terjemahan Yudi Santoso. Bandung : Nusa Media

Mardiasmo. 2002. Otonomi Daerah dan Manajemen Keuangan Daerah. Yogyakarta : Andi

Mardiasmo. 2009. Akuntansi Sektor Publik. Yogyakarta : Andi

Myers, Margaret. 2000. Qualitative Research and The Generalizability Question: Standing Firm with Proteus. The Qualitative Report. (Vol. 4), Num. 3/4

Profil Desa Kobo Kecil Tahun 2015

Profil Desa Moyag Tahun 2015

Republik Indonesia. 2015. Rincian Pendapatan dan Belanja Negara Tahun Anggaran 2016. Peraturan Presiden No. 137

2014. Pengelolaan Keuangan Desa. Peraturan Menteri Dalam Negeri No. 113

2015. Penetapan Prioritas Penggunaan Dana Desa Tahun 2016. Peraturan Menteri Desa, Pembangunan Daerah Tertinggal dan Transmigrasi No. 21

2016. Tata Cara Pengalokasian, Penyaluran, Penggunaan, Pemantauan dan

Evaluasi Dana Desa. Peraturan Menteri Keuangan No. 49/PMK.07/2016

2015. Perubahan Atas Peraturan Pemerintah No. 60 Tahun 2014 Tentang Dana

Desa yang bersumber dari Anggaran Pendapatan dan Belanja Negara. Peraturan Pemerintah No. 22

2014. Peraturan Pelaksana Undang-undang Nomor 6 Tahun 2014. Peraturan

Pemerintah No. 43

2010. Standar Akuntansi Pemerintahan. Peraturan Pemerintah No. 71

Ruky, S. Achmad. 2001. Sistem Manajemen Kinerja. Cetakan Keempat. Jakarta : Gramedia Pustaka Utama

Santoso, Eko. 2011. Efisiensi dan Efektivitas Pengelolaan Keuangan Daerah di Kabupaten Ngawi.

Tesis : Fakultas Ekonomi Universitas Sebelas Maret Surakarta

Satori, Djam'an dan Aan Komariah. 2014. Metodologi Penelitian Kualitatif. Bandung : CV. Alfabeta

Silalahi, Bonar P, Khaira Amalia F dan Muslich Lufti. 2014. Pengaruh Motivasi, Pengawasan dan Disiplin Kerja terhadap Prestasi Kerja Pegawai Dinas Pendapatan, Pengelola Keuangan dan Kekayaan Daerah Kabupaten Tapanuli Tengah. Jurnal Bisnis dan Manajemen Eksekutif. (Vol. 1, No. 1) Artikel 2

Smith, W. Robert and Mark Bertozzi. 1998. Principals and Agents : An explanatory model of public budgeting. Journal of Public Budgeting and Financial Management (Fall): 325-353

Sudjatmiko, Budiman dan Yando Zakaria. 2015. Desa Kuat, Indonesia Hebat. Jakarta : PT. Buku Seru

Sugiyono. 2014. Memahami Penelitian Kualitatif. Bandung : CV. Alfabeta

Sujarweni, Wiratna. 2015. Akuntansi Desa. Yogyakarta : Pustaka Baru Press

Sukanto. 2014. Efektifitas Alokasi Dana Desa dan Kemiskinan di Provinsi Sumatera Selatan. Tesis : Fakultas Ekonomi Universitas Sriwijaya

Sumiati. 2015. Pengelolaan Alokasi Dana Desa pada Desa Ngatabaru Kecamatan Sigi Biromaru Kabupaten Sigi. Tesis : Program Studi Magister Administrasi Publik Universitas Tadulako

Suparman, dan Dedi Kusnadi, Dwi Haryono. 2014. Implementasi Program Alokasi Dana Desa di Kecamatan Sukadana Kabupaten Kayong Utara. Tesis : Program Studi Ilmu Administrasi Negara Magister Ilmu Sosial Fakultas Ilmu Sosial dan Ilmu Politik Universitas Tanjungpura Pontianak 
Tahir, Arifin. 2014. Kebijakan Publik \& Transparansi Penyelenggaraan Pemerintah Daerah. Bandung: CV. Alfabeta

Vaismoradi, Mojtaba, Hannele Turunen and Terese Bondas. 2013. Content Analysis and Thematic Analysis : Implications for conducting a qualitative descriptive study. Nursing and Health Sciences Journal. (Vol. 15): 398-405

Yasa, Murjana. 2008. Penanggulangan Kemiskinan Berbasis Partisipasi Masyarakat di Provinsi Bali. Jurnal Ekonomi dan Sosial. (Vol. 1 No. 2) : 86-91

Yusuf, Burhanuddin. 2015. Manajemen Sumber Daya Manusia di Lembaga Keuangan Syariah. Jakarta : PT. Raja Grafindo Persada

Ysw. 2014. Dana Desa : Berkah atau Petakah?. Halaman : http://nasional.sindonews.com/read/905681/16/dana-desa-berkah-atau-petaka1411743403/ diakses pada tanggal 2 Juli 2016

Wisakti, Daru. 2008. Implementasi Kebijakan Alokasi Dana Desa di wilayah Kecamatan Geyer Kabupaten Grobogan. Tesis : Program Studi Magister Ilmu Administrasi Universitas Diponegoro Semarang

Wiyantoro, L. Sugeng dan Arifin Sabeni. 2007. Hubungan antara Sistem Pengendalian Manajemen dengan perilaku Dysfunctional : Budaya Nasional sebagai variabel moderating. Tesis : Program Studi Magister Sains Akuntansi Universitas Diponegoro Makasar 